\title{
Rotten context: the unaffordability of technological advances
}

\author{
Henk ten Have ${ }^{1} \cdot$ Bert Gordijn $^{1}$
}

Published online: 11 September 2015

(C) Springer Science+Business Media Dordrecht 2015

This issue illustrates that progress in healthcare depends on advancements in science and technology, as well as on careful and precautious clinical trials, exchange of experimental data and critical examination of clinical findings. New technological applications such as deep brain stimulation, the creation of human-nonhuman chimeras, and mitochondrial replacement techniques as analyzed in contributions in this issue, raise basic ethical questions that also need to be explored. However, this scientific and technological optimism is only part of the story of promoting and expanding healthcare. Within the present climate of pervasive social, economic, and political inequalities, new scientific knowledge and technological applications are often not available to everyone who needs to them. Growing inequality is now considered as a major risk for political stability, undermining democracy and political institutions (Schui 2014). The social fabric responsible for equality of opportunity, which used to be typical for the US, is gone (Putnam 2015). The same situation occurs in Europe; solidarity, which used to be lauded as a typical European principle, is dead. The damaging effects of neoliberal economic policies are particularly clear in the breakdown of healthcare systems in many developing countries, and also nowadays increasingly in developed countries such as Greece (Streeck 2014). Reduced expenditures for health and social services, privatization of care, lower salaries for healthcare workers, and introduction of user fees for patients have reduced access to health services for the majority of populations. Entire populations are deprived of necessary treatment and

\footnotetext{
Henk ten Have

tenhaveh@duq.edu

1 Pittsburgh, PA, USA
}

medication, simply because the costs are unaffordable or because healthcare is inaccessible (Keshavjee 2014). For example, globally, each year, 2-3 million people die of tuberculosis; they could be treated but $79 \%$ of them do not have access to appropriate medication (WHO 2015). The context of neoliberal policies therefore determines whether, how and for whom new medical and technological opportunities will be available.

Bioethics discourse, however, rarely addresses this biopolitical context; it is even more uncommon that it critically scrutinizes it. Often, it is simply assumed that this context cannot be examined because it is not within the remit of ethical discourse. Ethics prefers to concentrate on individual decisions on whether and how to use new clinical and research opportunities without asking questions about the social, economic and political conditions within which such decisions are made. An exception is the contribution of Tom Andreassen (Andreassen 2015) in this issue. He analyses the ethical justifications for biotech patents. His analysis draws attention to one of the major changes in the background of the bioethical debate since the 1980s: the commercialization of health and knowledge. The globalization of the intellectual property rights regime has imposed an unfair institutional order, as argued by Thomas Pogge (2013). The establishment of the World Trade Organization (WTO) and the Agreement on Traderelated Aspects of Intellectual Property Rights (TRIPS) in 1994 and 1995 were the outcome of coordinated pressures on developing countries of Western countries and international businesses as the owners of property rights (Baldwin 2014). There was no fair representation of countries involved, no sharing of full information, no democratic bargaining but a mixture of political and economic threats and coercion. Public involvement was also absent; all negotiations were behind closed doors. 
Countries were pressured to comply through bilateral trade agreements. The WTO has a dispute settlement system that can apply punitive measures if countries violate the rules. But it is not only the process that is unfair. The globalization of intellectual property has primarily benefitted Western countries. Owners of intellectual property have created the international legal context in their primary interest (Sell and Prakash 2004). The intellectual property rights regime is an illustration that the global context of health and healthcare itself can be unfair. By requiring that all fields of technology are patentable, TRIPS not only introduced patenting of pharmaceutical products across the world but also burdened many developing countries with the need to establish legislation and bureaucratic systems. Because they lack adequate infrastructure many countries are not able to take advantage of intellectual property protection. There is not much evidence that this protection promotes innovation in developing countries (Lessig 2004). And if there is, the focus is on the needs of developed countries as the most attractive market. At the same time, developing countries face disadvantages since TRIPS makes it very difficult to use generic medication as an alternative to pricy imported patented drugs. Due to growing criticism, particularly relating to the lack of access to affordable medication, the strict implementation of property rights has been mitigated. The Doha Declaration (adopted in 2001) is regarded as a success for developing countries arguing that public health and the right to health are more important than protecting patent rights. However, in practice developing countries cannot use these flexibilities to trade-off public health against commercial interests to promote access to medicines. A major reason is that more and more regional and bilateral free trade agreements are signed with the European Union and the United States including intellectual property rights provisions that are more stringent than the requirements of the TRIPS agreement. For example, they extend the duration of patents and they introduce exclusive protection of test data for drugs. In the last case, data obtained in clinical trials and submitted to get approval of a new drug cannot be used to get approval for a generic drug. The result is that countries cannot develop or buy less expensive generic medication for their population. Bilateral agreements have thus undermined the Doha Declaration. The Obama Administration in particular has a consistent policy of imposing TRIPS-plus requirements, in return for Big Pharma's support for the Affordable Care Act (for example a 12-year monopoly on test data for clinical trials). This will not only prevent the development of new drugs but also raise prices. Although WTO has never imposed such standards, they are now included in secretly negotiated trade deals, such as the Trans-Pacific Partnership. Leaked documents show that the issue of intellectual property rights plays a major role
(Public Citizen 2015). The trade agreement will make the approval process for generic medication more difficult; patents will be longer applicable; knowledge will be restricted (Gillmor 2013). For many countries in the Pacific area it will lead to dramatic increases of life-saving medication. The Transatlantic Trade and Investment Partnership between the EU and the US (TTIP), also currently negotiated behind closed doors, has the same ingredients. According to Oxfam, TTIP will allow companies to bypass national courts and governments if they permit competition with cheaper versions of medication (Oxfam 2015).

Within this prevailing context of trade and commerce, basic goods such as health, education, and knowledge are translated into money. New scientific and technological advances - though they might be exciting and fascinating in themselves - are only available to those who can afford them, which is currently a shrinking population. Jennifer Chan in her recent book on AIDS activism and global health governance highlights the international trade system and the role of WTO, as "the rot at the core of global governance today" (Chan 2015, p. 177). Where is bioethical criticism in this connection? Blaming economic injustice and structural violence as fundamental ethical problems is unusual in bioethics. Can bioethics afford to continue its focus on the individual interactions, the clinical encounter, the applicability of new interventions in individual patients without addressing the political, social and commercial context of the world in which such interactions are taking place?

\section{References}

Andreassen, T. 2015. Ethical reasons for narrowing the scope of biotech patents. Medicine Health Care and Philosophy 18(4): this issue.

Baldwin, P. 2014. The copyright wars. Three centuries of transatlantic battle. Princeton, Oxford: Princeton University Press.

Chan, J. 2015. Politics in the corridor of dying. AIDS activism and global health governance. Baltimore: Johns Hopkins University Press.

Gillmor, D. 2013. Thanks to Wikileaks, we see just how bad TPP trade deal is for regular people. The Guardian 13 November 2013. http://www.theguardian.com/commentisfree/2013/nov/13/ trans-pacific-paternership-intellectual-property.

Keshavjee, S. 2014. Blind spot. How neoliberalism infiltrated global health. Oakland: University of California Press.

Lessig, L. 2004. Free culture. The nature and future of creativity. New York: Penguin Books.

Oxfam. 2015. Comments on the TTIP. https://www.oxfam.org/en/ whats-wrong-european-union-united-states-free-trade-talks.

Pogge, T. 2013. World poverty and human rights. Cosmopolitan responsibilities and reforms, 2nd ed. Cambridge, UK, Malden, MA: Polity Press.

Public Citizen. 2015. Trans-Pacific Partnership (TPP): Job loss, lower wages and higher drug prices. http://www.citizen.org/TPP. 
Putnam, R.D. 2015. Our kids: The American dream in crisis. New York: Simon \& Schuster.

Schui, F. 2014. Austerity; the great failure. New Haven: Yale University Press.

Sell, S.K., and A. Prakash. 2004. Using ideas strategically: The contest between business and NGO networks in intellectual property rights. International Studies Quarterly 48: 143-175.
Streeck, W. 2014. Buying time. The delayed crisis of democratic capitalism. Verso: London, New York.

WHO. 2015. Tuberculosis http://www.who.int/trade/glossary/story092/ en/. 